TREE-RING RESEARCH, Vol. 60(2), 2004, pp. 69-76

\title{
EFFECTS OF PANDORA MOTH OUTBREAKS ON PONDEROSA PINE WOOD VOLUME
}

\author{
JAMES H. SPEER* \\ Department of Geography, Geology, and Anthropology \\ Indiana State University \\ Terre Haute, IN 47809, USA \\ and \\ RICHARD L. HOLMES ${ }^{I}$ \\ Laboratory of Tree-Ring Research \\ The University of Arizona \\ Tucson, AZ 85721, USA
}

\begin{abstract}
Coloradia pandora (Blake) is a phytophagous insect that defoliates Pinus ponderosa (Dougl. ex Laws.) in south-central Oregon. Little is known about the extent of damage this insect inflicts upon its host trees during an outbreak. In this paper, we present stem analyses on four dominant Pinus ponderosa trees that enable us to determine the amount of volume lost during each Coloradia pandora outbreak on this site for the past 450 years. We found that on average an outbreak inhibits radial growth so that an individual tree produces $0.057 \mathrm{~m}^{3}$ less wood volume than the potential growth for the duration of an individual outbreak. A total of $0.549 \mathrm{~m}^{3}$ of growth per tree was inhibited by 10 outbreaks during the lifetime of the trees, which, in this stand, equates to $9.912 \mathrm{~m}^{3} / \mathrm{ha}(1,700$ board feet/acre) of wood suppressed over the last 450 years throughout the stand. Our results do not support previous findings of a lag in suppression onset between the canopy of the tree versus the base. Crossdating of stem analysis samples is paramount to definitively examine the potential for a lagged response throughout the tree, which has bearing on the mechanisms of growth initiation and as well as the tree's stored reserves.

Keywords: Dendroecology, ponderosa pine, pandora moth, insect outbreaks, stem analysis, dendrochronology.
\end{abstract}

\section{INTRODUCTION}

Quantification of growth reduction inflicted on the host trees during insect outbreaks permits an accurate assessment of the aggregate effect of insects on forest productivity and health. Potential wood volume of a forest stand can be reduced during insect outbreaks through mortality of host trees or by suppression of radial growth. Pandora moth (Coloradia pandora Blake) outbreaks rarely cause

\footnotetext{
* Corresponding Author: gespeer@isugw.indstate.edu

${ }^{1}$ This paper is dedicated to Richard Holmes who passed away on July 8, 2003. Richard's contributions to the dendrochronological community will never be forgotten.
}

mortality, but volume reduction from defoliation can be substantial and should be considered in the management of ponderosa pine (Pinus ponderosa Dougl. ex Laws.) forests (Massey 1940; Wickman 1963; Koerber and Wickman 1970). An accurate assessment of wood volume loss caused by pandora moth defoliation would enable forest managers to estimate the overall effect on forest production.

Radial growth reduction from insect defoliation can vary throughout the bole of the tree. Greater growth reduction in the crown of the tree, where the defoliation actually occurs, has been documented with spruce budworm and Douglas-fir tus- 
sock moth outbreaks (Mott et al. 1957; Wickman 1963; Koerber and Wickman 1970; Alfaro et al. 1985). However, growth reduction could be greater at the base of the tree, furthest away from the site where auxin (a growth hormone) is produced (Onaka 1950; Fritts 1976). Understanding the effect of defoliation on radial growth throughout the tree enables assessment of whether cores taken at breast height accurately represent the overall growth reduction in ponderosa pine stems.

Stem analysis permits accurate estimates of wood volume loss from insect defoliation. By analyzing the entire stem of a tree, we can observe how defoliation affects wood production at different heights in the tree. In this paper we present the results from a stem analysis conducted on four ponderosa pine trees in central Oregon that have been repeatedly defoliated by pandora moth. Multiple samples (up to 14 cross-sections) were taken from each tree to determine the effect that defoliation had on the wood volume. In a previous paper, Speer et al. (2001) demonstrated that pandora moths have been an active disturbance agent in this region for at least the past 600 years. The purpose of this paper, therefore, is not to provide rationale for the control of pandora moth outbreaks, but to quantify the effect of these outbreaks on the growth of ponderosa pine trees in Oregon, adding to our understanding of the overall effect of insect outbreaks on forest dynamics.

\section{METHODS}

\section{Site Description and Pandora Moth Characteristics}

The study site is located within the Pringle Falls Research Natural Area near the town of La Pine, $50 \mathrm{~km}$ south of Bend in central Oregon. This area is part of the Deschutes National Forest (elevation 1,460 $\mathrm{m}$ a.s.1.). The physiographic region is known as the High Lava Plains Province and is punctuated by old cinder cones. Volcanic ash and pumice provide a loose porous soil conducive to pandora moth pupation (Patterson 1929; Massey 1940; Carolin and Knopf 1968).

The climate is semi-arid, with an orographic rainshadow effect from the Cascade Range restricting rainfall to between $500 \mathrm{~mm}$ and 1,000 $\mathrm{mm}$ a year, most $(75 \%)$ of which falls in the winter months as snow. According to dendroclimatic reconstructions, this area experiences occasional droughts, usually lasting from three to 10 years (Keen 1937; Garfin and Hughes 1996). The loose pumice soil has unusually high water retention, providing enough available moisture to sustain trees through the droughts (Franklin and Dyrness 1988).

Pandora moth is a phytophagous insect that defoliates pine trees throughout the western United States. It has a two-year life cycle with the heaviest feeding occurring in the second summer after the eggs hatch (Massey 1940). This two-year cycle allows the trees to recover in the intervening period so that very little mortality is associated with pandora moth outbreaks.

The study sites are dominated primarily by old growth ponderosa pine, with an understory of snowbrush ceanothus (Ceanothus velutinus Dougl. ex Hook) or bitter-brush (Purshia tridentata Pursh.) (Franklin and Dyrness 1988). Most of the underbrush on this site was removed by prescribed burns in 1989 and 1994. Char was still evident on most of the tree trunks, and pine regeneration was patchy.

\section{Field and Laboratory Techniques}

Stem analysis has been used extensively to investigate the effects of insect defoliation on plant resources allocation. The standard technique, with refinements by Duff and Nolan (1953, 1957), involves taking multiple cross-sections along the stem of the tree. Duff and Nolan (1957) and LeBlanc (1990) suggested cutting a section midway between internodes to quantify height and radial growth in every year. For trees a few centuries in age, it is very difficult or impossible to identify internodes on the external surfaces of the main stem. Thus, with increasing age it becomes impractical to determine all of the height increments.

We removed half cross-sections from four dominant ponderosa pine trees that were blown down by a storm in the winter of 1995/1996. The number of trees sampled was restricted because of the intensity of the labor in conducting a stem analysis on trees that average 450 years in age and also 

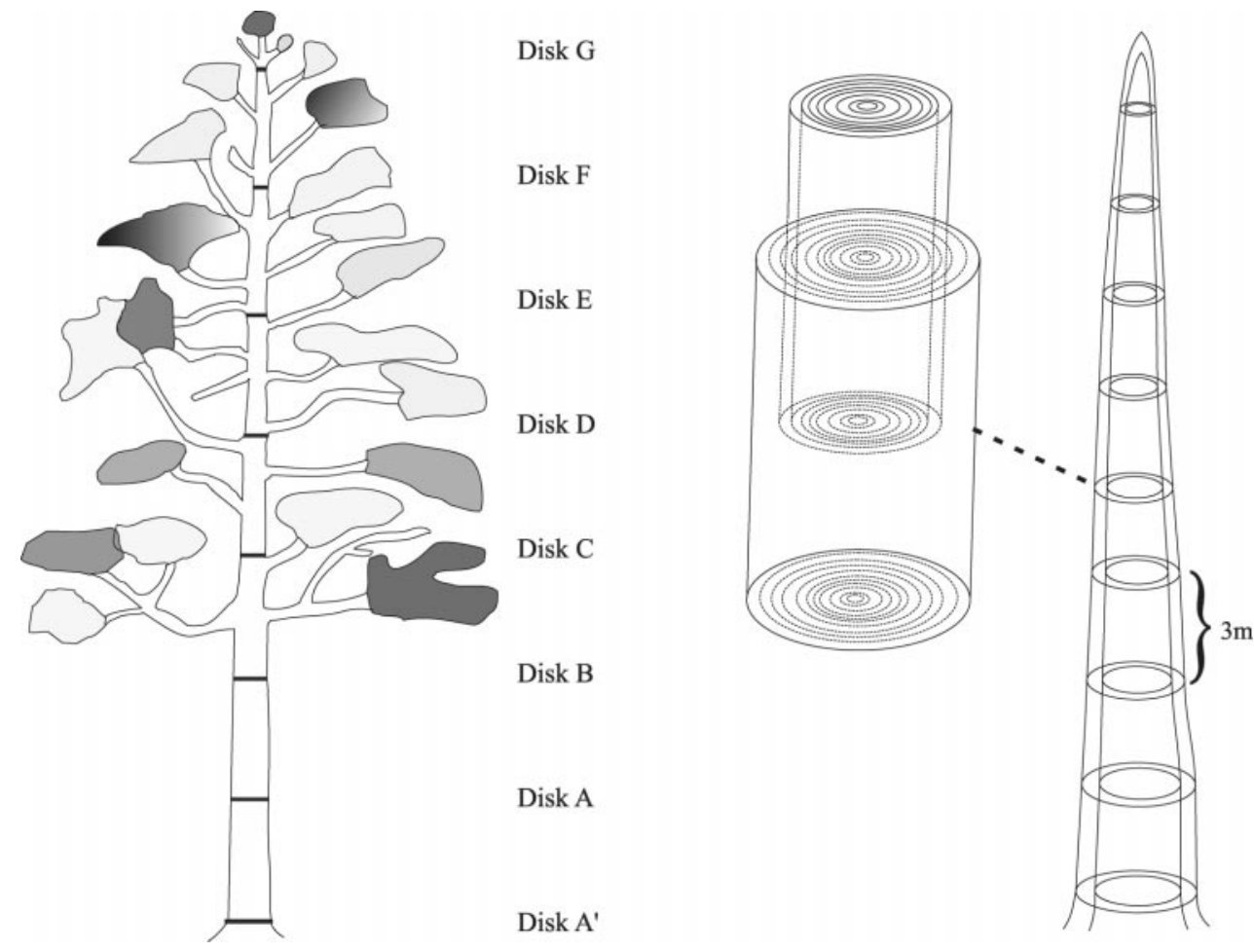

Figure 1. A cross-section was taken every three meters along the main stem of the ponderosa pine trees. For the volume calculation the trees were assumed to be a set of telescoping cylinders with each cylinder centered on a cross-section. (This graphic is modified from an unpublished report by Raske.)

because of restrictions on destructive sampling in a Research Natural Area. Half cross-sections were removed because this is a Research Natural Area and the land manager did not want the trees cut all the way through resulting in faster decay. We selected four trees that had no external evidence of fire damage or other injury and were more than 30 meters tall and greater than a half meter in diameter at breast height (DBH). Using a chain saw, we cut five-centimeter-thick cross-sections at three-meter intervals along each tree, beginning at three meters above the root crown to avoid the fractured bases of the fallen trees. The cross-sections were air-dried for one month and then surfaced using a belt sander with progressively finer grits of sandpaper from ANSI 60-grit (250-297 $\mu \mathrm{m})$ through ANSI 400-grit (20.6-23.6 $\mu \mathrm{m})(\mathrm{Or}-$ vis and Grissino-Mayer 2002).

We drew three radii $90^{\circ}$ apart on each sanded section, placing each radius in the same orientation up the tree. We crossdated each radius using skel- eton plots (Stokes and Smiley 1996) and then measured the ring widths along each transect using a Henson Measuring system with $0.01 \mathrm{~mm}$ precision. The computer program TREEGROW was developed to average the three radii from each section and determine the average ring width at that height increment. Average ring widths were plotted in stem profiles to evaluate how pandora moth outbreaks affected growth over the entire tree. The periods of ring-growth suppression caused by outbreaks were initially identified from cores taken at breast height (Speer 1997; Speer et al. 2001).

We evaluated these outbreaks by calculating the volume growth reduction throughout the tree and the percent growth reduction on each individual disc along the tree. TREEGROW used multiple radii averages from each disc to calculate an approximate basal area increment. Using a simplified telescoping-cylinder model, we determined the volume of the entire tree from the basal area increments at each cross-section (Figure 1). We es- 

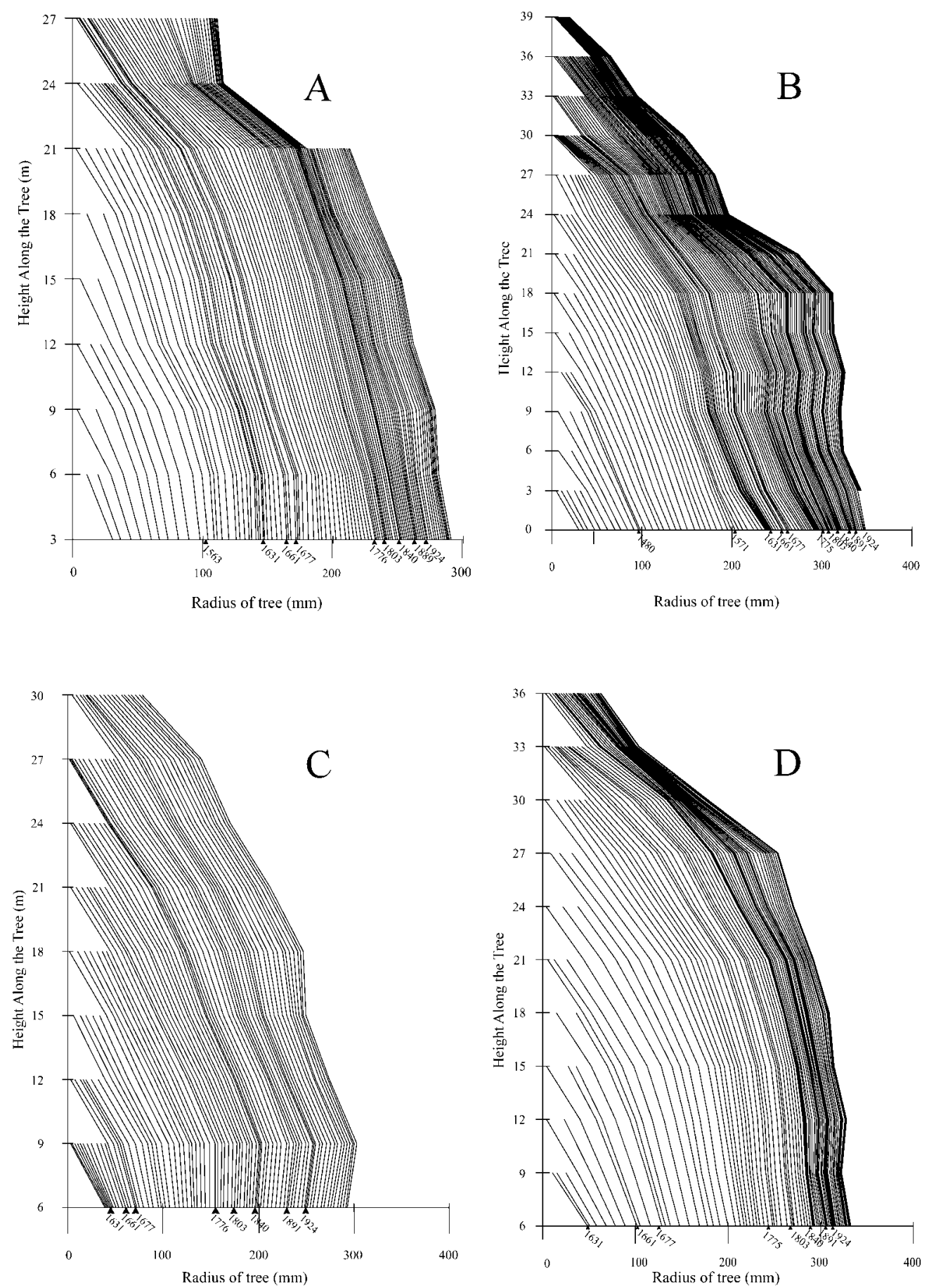

Figure 2. Stem profiles with ring width averaged every five years. The outbreaks are evident from the 5 to 15 years of compressed growth. Tree number RNA01 (A) established in 1497, RNA02 (B) established in 1428, RNA03 (C) established in 1607, RNA04 (D) established in 1626. All tree profiles are flat topped because the trees terminated before they reached the next three-meter height interval. RNA01 has a discontinuity in the ring pattern from the discs at 21 meters and above because the tree was severely suppressed and experienced apical dieback. 
timated the hypothetical volume of the tree without insect defoliation by extrapolating a curve fit from ten years prior to the outbreak to the basal area increment chronology developed from each disc, through the period of outbreak-related suppression based on the mean of the other series. We calculated the volume reduction from the difference between the hypothetical volume and the actual volume of wood at the end of each outbreak using the equation

$$
\mathrm{V}=\left(\mathrm{R}_{\mathrm{n}}^{2} \mathrm{H}_{\mathrm{n}}-\mathrm{R}_{\mathrm{o}}^{2} \mathrm{H}_{\mathrm{o}}\right) \pi / 3
$$

where $\mathrm{V}$ is the volume reduction, $\mathrm{R}_{\mathrm{n}}$ is the radius if no outbreaks occurred, calculated by

$$
\mathrm{R}_{\mathrm{n}}=\mathrm{R}_{\mathrm{o}}+\mathrm{R}_{\mathrm{r}}
$$

$R_{o}$ is the radius after an outbreak, $R_{r}$ is the radial reduction resulting from the outbreak. $H_{n}$ is the height if no outbreak occurred described by

$$
\mathrm{H}_{\mathrm{n}}=\mathrm{H}_{\mathrm{o}}^{*} \mathrm{R}_{\mathrm{n}} / \mathrm{R}_{\mathrm{o}}
$$

where $\mathrm{H}_{\mathrm{o}}$ is the height after outbreak based on the highest cross-section that showed suppression from that outbreak.

To account for tree-specific variation, all volume-reduction measurements for a given outbreak period were averaged to yield a mean volume reduction, which represents the relative severity of the particular outbreak. The mean volume reduction was then divided by the number of years in the outbreak period to determine the total annual volume reduction. This provides a measure of outbreak severity independent of the length of the outbreak.

\section{RESULTS}

The four trees used in this stem analysis ranged from 371 years to 569 years in age, with as many as 10 pandora moth outbreaks recorded on a single tree. Ring-width suppressions were evident throughout the entire stem on all trees (Figure 2). For a single outbreak, the volume reduction ranged from $0.001 \mathrm{~m}^{3}$ to $0.146 \mathrm{~m}^{3}$, with at least $0.026 \mathrm{~m}^{3}$ lost from trees from which we had samples at all heights along the stem analysis. The average reduction for a single outbreak was $0.057 \mathrm{~m}^{3}$ for a mature tree. Variations in cumulative volume re-
Table 1. Growth reduction resulting from 10 pandora moth outbreaks in ponderosa pine in eastern Oregon.

\begin{tabular}{lcccc}
\hline Outbreak & $\begin{array}{c}\text { RNA01 } \\
\text { Vol. }\left(\mathrm{m}^{3}\right)\end{array}$ & $\begin{array}{c}\text { RNA02 } \\
\text { Vol. }\left(\mathrm{m}^{3}\right)\end{array}$ & $\begin{array}{c}\text { RNA03 } \\
\text { Vol. }\left(\mathrm{m}^{3}\right)\end{array}$ & $\begin{array}{c}\text { RNA04 } \\
\text { Vol. }\left(\mathrm{m}^{3}\right)\end{array}$ \\
\hline $1479-1489$ & **** & 0.039 & **** & **** \\
$1563-1577$ & 0.040 & 0.077 & **** & **** \\
$1631-1638$ & 0.022 & 0.030 & 0.001 & 0.007 \\
$1661-1666$ & 0.029 & 0.043 & 0.002 & 0.034 \\
$1677-1686$ & 0.052 & 0.064 & 0.009 & 0.091 \\
$1775-1783$ & 0.032 & 0.036 & 0.017 & 0.080 \\
$1802-1811$ & 0.026 & 0.038 & 0.013 & 0.124 \\
$1840-1853$ & 0.044 & 0.082 & 0.062 & 0.146 \\
$1889-1902$ & 0.022 & 0.061 & 0.048 & 0.072 \\
$1923-1931$ & 0.014 & 0.071 & 0.060 & 0.059 \\
Total & 0.281 & 0.541 & 0.212 & 0.613 \\
\hline
\end{tabular}

$* * * *$ This outbreak is not recorded because the particular tree was not old enough to reflect the effect of defoliation at the time.

duction for all outbreaks occurred among the trees, with two trees having less than half the overall volume loss of the other two trees (Table 1). An average of $0.549 \mathrm{~m}^{3}$ of growth per tree was inhibited by 10 outbreaks during the lifetime of the trees. Assuming that the four trees sampled in this study are representative of the amount of damage occurring throughout the whole stand and based on the stand density measurements reported by Speer et al. (2001), pandora moth reduced the wood volume produced in this forest by $9.912 \mathrm{~m}^{3} /$ ha $(1,700$ board feet/acre).

The amount of volume loss within a given tree also varied along its length. The percent radial growth reduction tended to be greatest at the base of the tree, gradually decreasing up the stem, but with increased variability in the crown (Figure 3). Based on total annual volume reduction per outbreak, no temporal trend was apparent in the severity of outbreaks (Figure 4), neither was there any increase in the length of the outbreaks. The most severe outbreak occurred in the 1840s. The 20th Century outbreaks appeared to be within the range of severity and extent of prior recorded outbreaks (Figure 4).

\section{DISCUSSION}

Although pandora moth only causes 2\% mortality (Patterson 1929; Massey 1940; Bennett et al. 


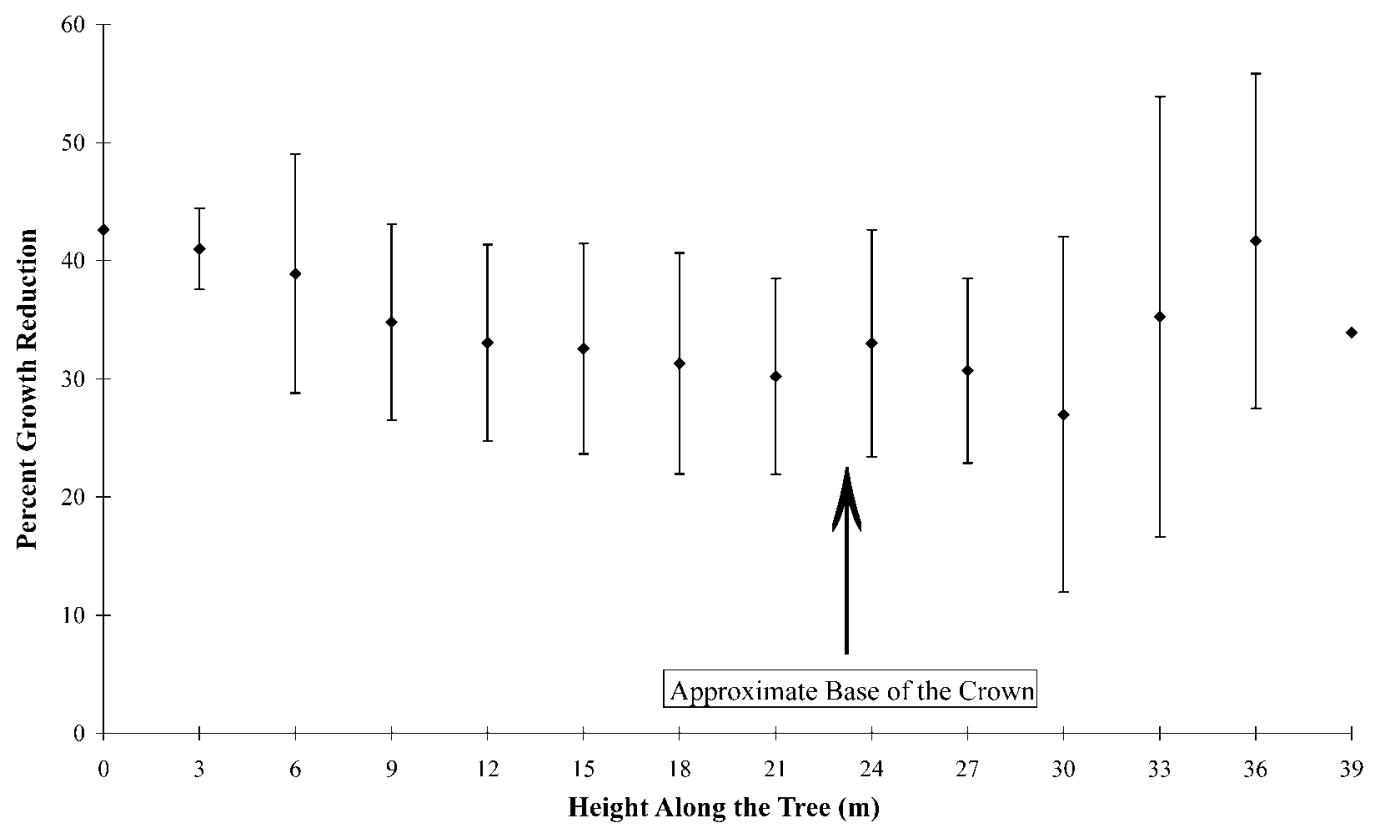

Figure 3. Percent radial growth reduction along the stem of the tree. This is the mean of all four trees for all outbreaks recorded by each tree. The bars represent the standard deviation for each value. Samples at 0 and 39 meters height along the tree only have one sample each and therefore have no standard deviation.

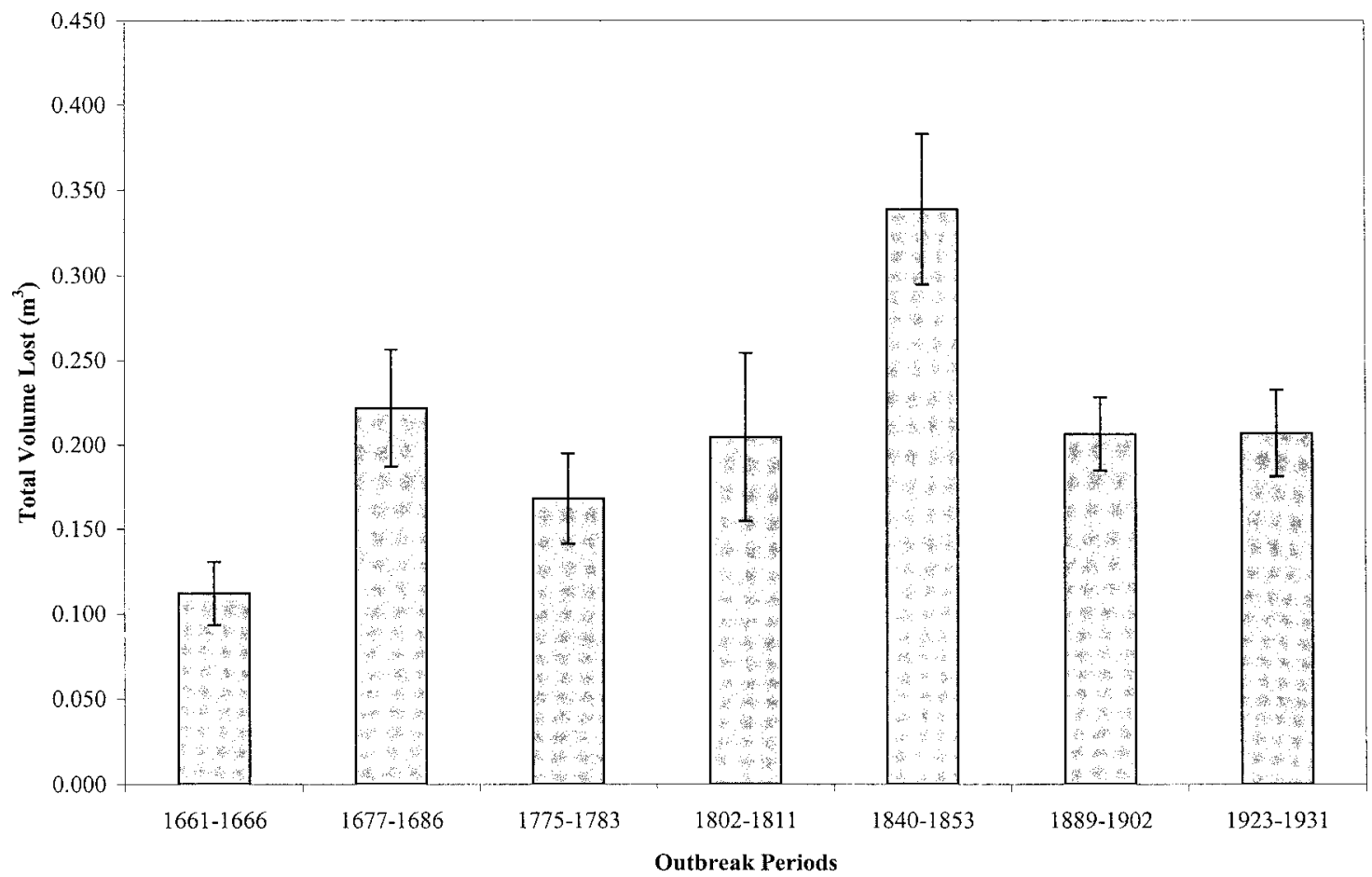

Figure 4. Total volume lost from all stem analysis trees listed by outbreak. Error bars indicate one standard deviation. 
1987), the amount of volume reduction from an outbreak also needs to be considered. On average an outbreak reduces ponderosa pine wood production by $9.912 \mathrm{~m}^{3} / \mathrm{ha}$ over approximately 450 years. This is the equivalent of removing one mature tree from the stand, but of course, the volume lost is distributed throughout all of the trees and occurs periodically as a result of each outbreak. This is another demonstration that the endemic pandora moth is well adapted to its host species of ponderosa pine and that this system is functioning in a balanced manner so that pandora moth outbreaks do not need to be controlled.

A lag between growth reduction in the canopy of the tree and the base of the tree has been noted in other stem analysis studies (Mott et al. 1957; Blais 1958; Wickman 1963; Krause and Morin 1999; Krause et al. 2003). This lag throughout the tree was not observed with pandora moth, possibly because pandora moths feed on old needles, and the first instance of heavy defoliation is usually abrupt, with severe defoliation occurring in a single year. A year lag in the effect of defoliation from the canopy to the base of the tree violates the growth hormone model of cell initiation in which less auxin would be produced in years with reduced photosynthates causing radial growth at the base of the tree (furthest from auxin production) to be reduced (Onaka 1950; Fritts 1976). Mott et al. (1957) did not crossdate the samples for their stem analysis; therefore the apparent lag in ring-growth response between canopy and base of the tree could be a result of inaccurate dating. Krause and Morin (1999) and Krause et al. (2003) did crossdate their samples and still demonstrate the lag in growth suppression in ecosystems involving spruce budworm (Choristoneura fumiferana), balsam fir (Abies balsamea), and black spruce (Picea mariana). Krause et al. (2003) suggest that the trees use reserves stored in the roots to enable growth at the base of the tree while the canopy is being suppressed. We need more crossdated stem analyses to be able to examine these questions about the factors that contribute to wood production.

The amount of volume loss varied drastically between the different trees. This variability was not, however, related to age or size of the trees.
This suggests that tree response to defoliation may depend on individual-tree factors (such as stored food reserves, vigor of the tree, and the intensity of defoliation). The greatest amount of suppression occurred at the base of the tree and the timing of the outbreaks were reliably recorded at this height, suggesting that increment cores from breast height are an accurate way to sample pandora moth outbreaks.

The work done in this stem analysis determined the range of volume reduction induced by pandora moth defoliation that occurred in four ponderosa pine trees. These results reveal how pandora moth defoliation affects wood volume production in the whole tree thereby contributing to a better understanding of the effect of this phytophagous insect. The base of the tree (e.g. the bottom three meters) is an appropriate place to sample for pandora moth outbreaks because all of the outbreaks are represented and may show the greatest effect in this area. Further work needs to be conducted to determine the volumetric effects of insect defoliation, to examine the growth triggers and the timing of suppressions caused by insect defoliation, and to develop sampling standards for insect outbreak studies.

\section{ACKNOWLEDGMENTS}

Financial support was provided by the U.S. Department of Agriculture, Forest Service, Pacific Northwest Research Station, Cooperative Agreement Number PNW 95-0748. Thanks to Andy Youngblood and Boyd Wickman for their help in field logistics and obtaining permission for sampling this site. We would like to thank Dr. Thomas W. Swetnam and Dr. Malcolm K. Hughes for assistance with the fieldwork. Many thanks go to Peter Brown and Carolyn Copenheaver as well as several anonymous reviewers of this manuscript.

\section{REFERENCES CITED}

Alfaro, R. I., A. J. Thomson, and G. A. Van Sickle

1985 Quantification of Douglas-fir growth losses caused by western spruce budworm defoliation using stem analysis. Canadian Journal of Forest Research 15:5-9. 
Bennett, D. D., J. M. Schmid, S. A. Mata, and C. B. Edminster 1987 Growth impact of the North Kaibab pandora moth outbreak. USDA Forest Service Research Note RM474. 4 pp.

Blais, J. R.

1958 Effects of defoliation by spruce budworm (Chorisoneura fumiferana (Clem.)) on radial growth at breast height of balsam fir (Abies balsamea (L.) Mill.) and white spruce (Picea glauca (Moench.) Voss.). Forestry Chronicle 34:39-47.

Carolin, V. M., and J. A. E. Knopf

1968 The Pandora Moth. USDA Forest Service Forest Pest Leaflet $114.7 \mathrm{pp}$.

Duff, G. H., and N. J. Nolan

1953 Growth and morphogenesis in the Canadian forest species. Part I. The controls of cambial and apical activity in Pinus resinosa Ait. Canadian Journal of Botany 31:471-513.

Duff, G. H., and N. J. Nolan

1957 Growth and morphogenesis in the Canadian forest species. Part II. Species increments and their relation to the quantity and activity of growth in Pinus resinosa Ait. Canadian Journal of Botany 35:527-572.

Franklin, J. F., and C. T. Dyrness

1988 Natural Vegetation of Oregon and Washington. Oregon State University Press; 452 pp.

Fritts, H. C.

1976 Tree Rings and Climate. Academic Press, London; $567 \mathrm{pp}$.

Garfin, G. M., and M. K. Hughes

1996 Eastern Oregon Divisional Precipitation and Palmer Drought Severity Index from Tree-Rings. Unpublished Final Report USDA Forest Service Cooperative Agreement. PNW 90-174. Laboratory of TreeRing Research, The University of Arizona, Tucson, Arizona; $55 \mathrm{pp}$.

Keen, F. P.

1937 Climate cycles in eastern Oregon as indicated by tree rings. Monthly Weather Review 65(5):175-188.

Koerber, T. W., and B. E. Wickman

1970 Use of tree-ring measurements to evaluate impact of insect defoliation. In Tree-Ring Analysis with Special References to Northwestern America, edited by J. Smith and J. Worrall, University of British Columbia Faculty Forest Bulletin No. 7:101-106.

Krause, C., F. Gionest, H. Morin, and D. A. Maclean

2003 Temporal relations between defoliation caused by spruce budworm (Choristoneura fumiferana Clem.) and growth of balsam fire (Abies balsamea (L.) Mill.). Dendrochronologia 21(1):23-31.

Krause, C., and H. Morin

1999 Tree-ring patterns in stems and root systems of black spruce (Picea mariana) caused by spruce budworms. Canadian Journal of Forest Research 29(10):15831591.

LeBlanc, D. C.

1990 Red spruce decline on Whiteface Mountain, New York. I. Relationship with elevation, tree age, and competition. Canadian Journal of Forest Research 20:1408-1414.

Massey, C. L.

1940 The Pandora Moth (Coloradia pandora Blake), A Defoliator of Lodgepole Pine in Colorado. M.S. thesis, Duke University, Durham, North Carolina. 33 pp.

Mott, D. G., L. D. Nairn, and J. A. Cook

1957 Radial growth in forest trees and effects of insect defoliation. Forest Science 3(3):286-304.

Onaka, F.

1950 The Longitudinal Distribution of Radial Increments in Trees. Kyoto University Forests Bulletin 18. (In Japanese).

Orvis, K. H., and H. D. Grissino-Mayer

2002 Standardizing the reporting of abrasive papers used to surface tree-ring samples. Tree-Ring Research $58(1 / 2): 47-50$

Patterson, J. E.

1929 The Pandora Moth, a Periodic Pest of the Western Pine Forests. USDA Forest Service Technical Bulletin 137. 20 pp.

Speer, J. H.

1997 A Dendrochronological Record of Pandora Moth (Coloradia pandora, Blake) outbreaks in Central Oregon. M.S. thesis, The University of Arizona, Tucson, Arizona. 159 pp.

Speer, J. H., T. W. Swetnam, B. E. Wickman, and A. Youngblood

2001 Changes in pandora moth outbreak dynamics during the past 622 years. Ecology 82(3):679-697.

Stokes, M. A., and T. L. Smiley

1996 An Introduction to Tree-Ring Dating. The University of Arizona Press, Tucson.

Wickman, B. E.

1963 Mortality and Growth Reduction of White Fir Following Defoliation by the Douglas-fir Tussock Moth. USDA Forest Service Research Paper PSW-7. 14 pp.

Received 17 September 2003; accepted 22 July 2004. 